\title{
COMBINATION OF SILYMARIN AND CHOLINE BITARTRATE IN PREGNANCY INDUCED PRURITUS
}

\author{
Purvita Dam, Partha Sarathi Chakravorty, Suhrita De (Roy)
}

1. Associate Professor. Department of Obstetrics \& Gynaecology, North Bengal Medical College, Sushrut Nagar, Darjeeling.

2. Professor \& HOD. Department of Obstetrics \& Gynaecology, Malda Medical College, Malda.

3. Assistant Professor. Department of Obstetrics \& Gynaecology, Medical College, Kolkata.

\section{CORRESPONDING AUTHOR:}

Dr. Purvita Dam,

Flat - 5H, Block-5,

Avani Oxford, 136, Jessore Road,

Kolkata-700055.

E-mail: purvita_mdgo@yahoo.com

Ph: 00919830184589.

ABSTRACT: Intrahepatic cholestasis of pregnancy also known as Prurigo Gravidarum, often presents with symptoms mainly pruritus, severe enough to demand therapy and is of greater relevance due to its consequent fetal complications. Many drugs have been evaluated in its management, silymarin, a Milk Thistle extract being a promising modality. Considering that the bioavailability of Silymarin can be enhanced in combination with choline bitartrate, this study was conducted with the intention to establish that it can be a more safe and effective option for relieving pruritus and reducing complications. MATERIAL AND METHODS: A prospective randomized open labeled study was conducted on 20 antenatal patients second trimester onwards attending the Antenatal clinic, Medical College Kolkata from September 2009 to February 2010, suffering from pruritus and fulfilling both inclusion and exclusion criteriae. Apart from routine medications, they were prescribed $140 \mathrm{mg}$ silymarin and $450 \mathrm{mg}$ choline bitartrate thrice daily for 4 weeks and reassessment of parameters considered were done 7-10 days of therapeutic completion. Principal parameters evaluated included Itching area by rule of 5 , duration and severity of itching (objectively scored) and laboratory investigations especially liver function assessment. RESULTS: Itching score, area and duration were reduced in all patients. Serum SGOT and SGPT levels were reduced in $45 \%$ and $35 \%$ cases respectively. CONCLUSION: Therefore, the fixed drug regime comprising of silymarin and choline bitartrate evaluated in the trial definitely provided both symptomatic as well as biochemical relief to the patients. Perinatal and neonatal outcome were uneventful.

KEY WORDS: pregnancy pruritus, intrahepatic cholestasis, silymarin, choline bitartrate

INTRODUCTION: Milk thistle has been used medicinally since the fourth century BCE. Its use in treating hepatobiliary diseases dates back to the 1700 s, and its use as a liver protectant can be traced back to Greek references and has been well recorded over the past 2000yrs ${ }^{1}$. Pliny the Elder, a first century Roman writer, (AD 23 to 79) noted that the plant's juice was excellent for "carrying off bile." Nicholas Culpepper, the 17th century English herbalist, noted milk thistle to be useful against jaundice and for removing liver and spleen obstructions. Silymarin, the active ingredient responsible, a mixture of 3 isomeric flavonolignans was first isolated from this plant in 1968. Silymarin has a molecular formula of $\mathrm{C}_{25} \mathrm{H}_{22} \mathrm{O}_{10}$ and a molecular weight of 482.45 . 
The isomeric flavonolignans are silybin (silibinin), silychristin (silichristin), and silidianin (silidianin).

The mechanisms of action of silymarin involve different biochemical events, such as the stimulation of the synthetic rate of ribosomal RNA (rRNA) species through stimulation of polymerase I and rRNA transcription, protecting the cell membrane from radical-induced damage. Silymarin $420 \mathrm{mg} /$ day was also shown to improve indices of liver function [AST, ALT, $\gamma$-glutamyl transferase and bilirubin] in patients with liver disease of various aetiology. ${ }^{2}$

Pruritus is the main symptom of intrahepatic cholestasis of pregnancy (ICP) also known as Cholestasis of pregnancy, Jaundice of pregnancy, Obstetric cholestasis and Prurigo gravidarum ${ }^{3}$. It appears in late pregnancy although sometimes it can appear before week 20 of gestation. Pruritus appears in the palms and soles although its intensity fluctuates specially with nocturnal exacerbation. In some patients it is quite severe during the day and the night involving the entire skin surface, thus affecting the patient both physically and psychologically. Simultaneously with this symptom, liver function tests reflect a mild or moderate cholestasis. Both pruritus and biochemical anomalies disappear spontaneously after delivery. Pruritus itself is often reason enough to demand therapy, but of greater relevance for the need for an efficacious treatment is the fact that major consequence of ICP is its fetal complications, that is an increased fetal risk for prematurity, stillbirths, perinatal morbidity and mortality ${ }^{4}$. It has been noted that choline being itself a cholagogue makes silymarin more water soluble. Silybin phosphatidyl choline complexed as a phytosome provides significant liver protection and enhanced bioavailability over conventional silymarin. ${ }^{5}$ Hence a decision was taken to study the efficacy and safety of silymarin $140 \mathrm{mg}$ and choline bitartrate $450 \mathrm{mg}$ tablets in pregnant ladies in the treatment of pruritus through open label trials.

MATERIAL AND METHODS: Between September 2009 and February 2010, pregnant patients attending the antenatal clinic at Medical College Kolkata suffering from pruritus in pregnancy were screened for the study. Inclusion criteria included all pregnant women second trimester onwards suffering from pruritus in pregnancy while exclusion criteria included patients currently included in any other drug trial, as well patients having any other obstetrical or medical problems, skin infections or infestations. Study conducted was a prospective randomized open label study. 20 women who successfully complied to inclusion and exclusion criteria and voluntarily gave informed consent specially to comply with the study protocol of 6 weeks were included in the trial.

Detailed data collection included the following:

Date of inclusion into the study

PATIENT IDENTIFICATION: Age and parity- Age ranged between 20-40yrs, 10 patients were nullipara and 10 were primi or multipara.

Duration of gestation- As per onset of itching patients were included between 20 to 35 weeks of gestation.

History of similar pruritus in the past pregnancy

Regarding itching the following points were noted:

Itching area by rule of 5 (Legend 1) 


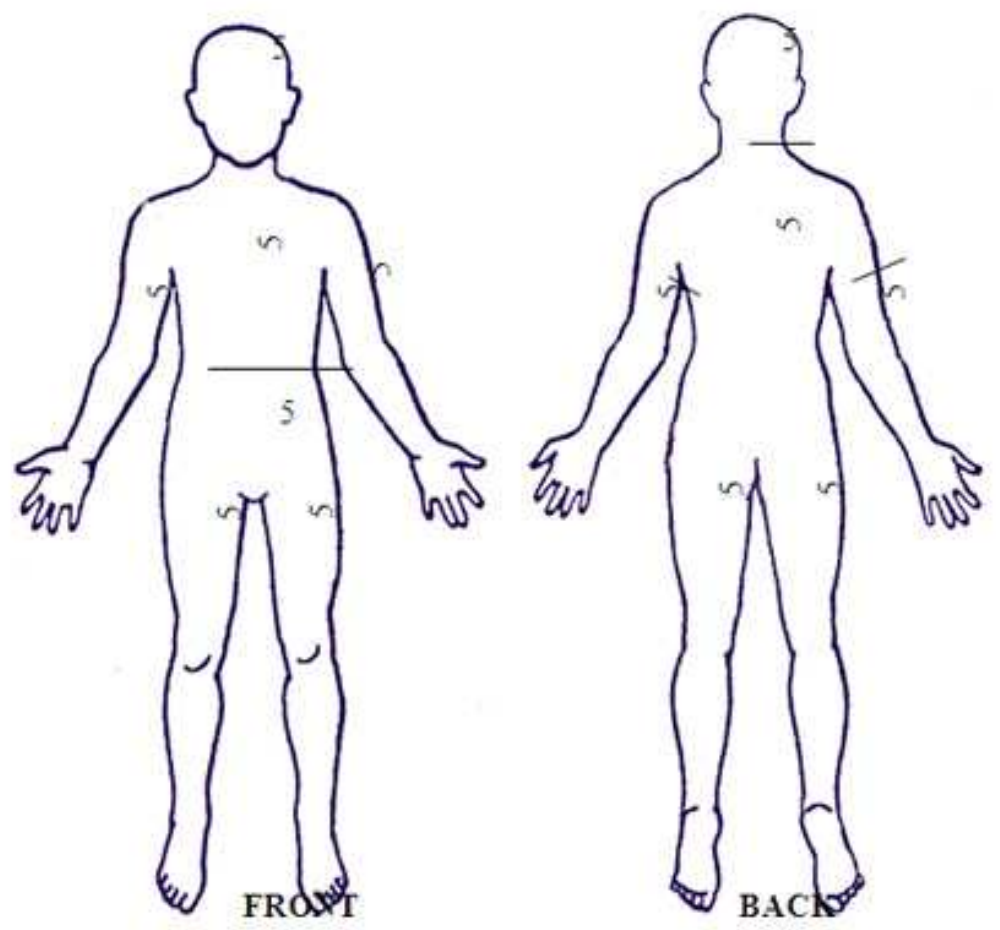

ITCHING SCORE

Duration of itching Morning/ Afternoon/ Evening/ Night(M/A/E/N)- each of 6hrs duration Severity of itching which was objectively scored-

Mild- no scratch marks, not itching during conversation- score 5

Moderate- scratch marks present, no sleep disturbance- score 10

Severe- scratch marks present, presence of sleep disturbance- score 15

Rashes present or absent

A thorough general examination was performed and the following points were notedincluding weight, pulse, blood pressure, temperature, jaundice, anemia, scratch marks and rashes

Several laboratory investigations were performed including the following-

1) Hemoglobin\%, TC, DC, fasting blood glucose, urea, creatinine

2) Bilirubin, SGPT, SGOT, Alkaline phosphatase

3) Serum albumin/ globulin ratio

All patients were provided with total medications of $140 \mathrm{mg}$ Silymarin and 450mg choline bitartrate thrice daily for 4 weeks and case report file was also handed to them, to note the special symptoms specially pruritus and any adverse reactions. Reassessment was done after 7 to 10 days of completion of therapy. Effect of the drug on symptoms of pruritus and on the different enzyme levels were noted, any adverse reaction was also looked for, any history of concomitant medication for any illness was also noted.

RESULTS: Initial and post treatment assessment was done in the following relevant tables. Itching area, score and severity were reduced in all patients. They are expressed in the following tables. 
Reduction in itching score was expressed in terms of percentage, i.e. whether the reduction was $1 / 4^{\text {th }}(25 \%), 1 / 2(50 \%), 3 / 4^{\text {th }}(75 \%)$ or more than $3 / 4^{\text {th }}$.

Table 1 Reduction in itching score

\begin{tabular}{|l|l|l|}
\hline Reduction in percentage & No of patients & Percentage of pts showing reduction \\
\hline$>75 \%$ & 8 & $40 \%$ \\
\hline $50-75 \%$ & 6 & $30 \%$ \\
\hline $25-50 \%$ & 4 & $20 \%$ \\
\hline$<25 \%$ & 2 & $10 \%$ \\
\hline
\end{tabular}

Thus almost $70 \%$ of the patients demonstrated a sizeable reduction in itching score.

Change in itching area over a period of 4 weeks as evaluated by the rule of 5 , was also expressed in terms of percentage. Reduction in itching area was expressed in terms of percentage, i.e. whether the reduction was by $25 \%, 50 \%$ or $75 \%$ or more than their initial situation.

Table 2 Reduction in itching area

\begin{tabular}{|l|l|l|}
\hline Reduction in percentage & No of patients & Percentage of patients showing the reduction \\
\hline$>75 \%$ & 12 & $60 \%$ \\
\hline $50-75 \%$ & \multicolumn{1}{|l|}{8} & $40 \%$ \\
\hline $25-50 \%$ & 0 & 0 \\
\hline$<25 \%$ & 0 & 0 \\
\hline
\end{tabular}

Hence almost $100 \%$ patients demonstrated a reduction in itching area.

Duration of itching was taken subjectively from patient records as stated in patient information data. Depending upon the quarters of the day (M/A/E/N) in which itching was present both before and after treatment, reduction in itching duration as per quarter reduction was expressed in terms of percentage.

Table 3 Reduction in itching duration

\begin{tabular}{|l|l|l|}
\hline Reduction in percentage & No of patients & Percentage of patients showing the reduction \\
\hline$>75 \%$ & 9 & $45 \%$ \\
\hline $50-75 \%$ & 7 & $35 \%$ \\
\hline $25-50 \%$ & 2 & $10 \%$ \\
\hline$<25 \%$ & 2 & $10 \%$ \\
\hline
\end{tabular}

Hence a good amount of reduction in itching duration was also observed in the trial.

Alteration in serum liver enzyme levels and albumin globulin ratio were recorded from our laboratory data and documented as whether they were raised, unaltered or had fallen. None of the patients had elevated bilirubin both in pre and post treatment estimations. Tropical eosinophilia or itching due to atopic dermatitis were possibly ruled out in all by estimating eosinophil levels. 
Table 4 Alteration in serum SGOT, SGPT, Alkaline Phosphatase, Albumin levels

\begin{tabular}{|l|l|l|l|l|l|l|l|l|}
\hline & \multicolumn{2}{|l|}{ Serum SGOT } & \multicolumn{2}{l|}{ Serum SGPT } & \multicolumn{2}{l|}{ Serum Alkaline Phosphatase } & \multicolumn{2}{l|}{ Serum Albumin } \\
\hline Rose & 5 & $25 \%$ & 6 & $30 \%$ & 15 & $75 \%$ & 1 & $5 \%$ \\
\hline Unaltered & 6 & $30 \%$ & 7 & $35 \%$ & 3 & $15 \%$ & 12 & $60 \%$ \\
\hline Fallen & 9 & $45 \%$ & 7 & $35 \%$ & 2 & $10 \%$ & 7 & $35 \%$ \\
\hline
\end{tabular}

Serum SGOT levels were reduced in $45 \%$ of patients, SGPT did not reveal any significant alteration. As was physiologically expected, alkaline phosphatase was raised in majority, where as albumin levels remained grossly unaltered in majority.

8 patients had mild rashes at the onset of therapy but none had at the conclusion of study.

All twenty patients were delivered in our institute; three underwent caesarean sections due to obstetrical reasons. All were term deliveries with birth weights ranging from $2.2 \mathrm{~kg}$ to 3.5 kg. One baby suffered from birth asphyxia due to acute fetal distress at the time of labour, but subsequently recovered. Rest of the babies had healthy neonatal periods.

DISCUSSION: Most women with pruritus in pregnancy present in the late second to third trimester with intense itching with mild rashes or without a rash as was noted in our patients. Generally the itching is localized to the abdomen, legs, palms and soles, but can be generalized.

HALLMARKS OF ICP INCLUDE THE FOLLOWING SYMPTOMS: Itching in particular limited to the palms of the hands and soles of feet, without rash. Itching increasing in the evening Itching that does not respond favourably to anti histamines or other anti-itch remedies Often elevated Liver function test results as well as raised serum bile acid counts. It is the second most common cause of jaundice in pregnancy. Luckily none of our patients had jaundice, clinically or biochemically.

Maternal consequences of the condition become itching, which can be intense and debilitating, premature labour and deranged clotting, which requires Vitamin K. Fetal consequences include meconium ingestion and aspiration syndrome. Possibly because of timely intervention, perinatal and neonatal outcome was very satisfactory in our patients.

The causes of intrahepatic cholestasis of pregnancy are still not fully understood. Hormones and genetic factors are likely to be important in the pathogenesis of the disease. A number of features of the disease suggest a link to hormones 6 . ICP occurs in the third trimester at the time when hormone levels are at their highest ${ }^{7}$. Multiple pregnancies associated with higher hormone levels, show higher incidence of ICP, the condition resolves quickly after delivery when placental hormones drop back to normal and first generation high dose estrogen oral contraceptive pills cause features of ICP. Both estrogen and progesterones have been implicated in this condition. In the short sample we studied there were two cases of multiple pregnancies.

Although it has been primarily known as a herb for the liver, silymarin exerts a number of important effects in the skin. ${ }^{8}$ Pruritus intrahepatic cholestasis of pregnancy is ameliorated by silymarin. ${ }^{9}$ Phosphatidyl choline is not merely a passive "carrier" for the bioactive flavonoids of the phytosomes, but is itself a bioactive nutrient with documented clinical efficacy for liver disease, including several liver diseases. So did choline bitartrate act in our trial in conjunction ith silymarin..$^{10}$ Hence the fact has actually been supported in our trial too. Therefore the fixed 
drug regime evaluated in the trial definitely provided both symptomatic as well as biochemical relief to the patients. Neonatal outcome was also satisfactory.

ACKNOWLEDGEMENT: We acknowledge Emcee Pharmaceuticals Private Limited for providing us whole hearted support in conducting the trial in every possible aspect.

We also acknowledge the contributions of Mr. Ashim Ghatak who worked hard to cooperate with us and played an important role in moderating the trial conduction.

\section{BIBLIOGRAPHY:}

1. Flora K, Hahn M, Rosen H, Benner K. Milk thistle (Silybum marianum) for the therapy of liver disease Am J Gastroenterol 1998 Feb; 93(2):139-43 Pubmed

2. Wellington, Keri; Jarvis, Blair, Silymarin: A Review of its Clinical Properties in the Management of Hepatic Disorders; BioDrugs: 2001 - Volume 15 - Issue 7 - pp 465-489.

3. Rapini, Ronald P.; Bolognia, Jean L; Jorizzo, Joseph L. (2007). Dermatology : 2-Volume Set. St Louis : Mosby. ISBN-4160-2999-0

4. Tunzi M, Gray GR (January 2007). " Common skin conditions during pregnancy". Am Fam Physician 75(2): 211-8

5. Parris K, Kathlin H, A review of the bioavailability and clinical efficacy of Milk Thistle Phytosome: A Silybin Phosphatidylcholine complex; Alternative Medicine Review Vol 10, 3, 2005, 193-194

6. Alan Datner, Silymarin, Dermatology online journal Vol 6 No 1.

7. Lammert F, Marschall HU, Glantz A, Matern S (December 2000). Intrahepatic cholestasis of pregnancy: molecular pathogenesis, diagnosis and management. J Hepatol. 33 (6): 1012-21.

8. Kreek MJ (February 1987). Female sex steroids and cholestasis. Semin Liver Disease. 7 (1): 8-23.

9. Reyes H, Simon FR, Intrahepatic cholestasis of pregnancy: an estrogen related disease, Semin Liver Dis 1993, August: 13, (3): 289-301

10. Kidd PM. Phosphatidylcholine (Monograph). In: Czap K, Miller AL, Head KA, et al, eds. Alternative Medicine Review Monographs Volume One. Dover, ID: Thorne Research, Inc.; 2002:310-15

\section{Chart showing pre and posttreatment values of various parameters in all the patient}

\begin{tabular}{|c|c|c|c|c|c|c|c|c|c|c|c|}
\hline $\begin{array}{l}\text { Srl } \\
\text { no }\end{array}$ & Age & $\mathrm{Wt}$ & Parity & $\begin{array}{l}\text { Gest } \\
\text { age at } \\
\text { starting }\end{array}$ & $\begin{array}{l}\text { Itchi } \\
\text { ng } \\
\text { time }\end{array}$ & $\begin{array}{l}\text { Itching } \\
\text { severiy }\end{array}$ & $\begin{array}{l}\text { Itching } \\
\text { score }\end{array}$ & Rashes & $\begin{array}{l}\text { Itchin } \\
\text { g area }\end{array}$ & $\begin{array}{l}\text { Bilirubin } \\
\text { conj }\end{array}$ & $\begin{array}{l}\text { Bilirubin } \\
\text { unconj }\end{array}$ \\
\hline \multirow[t]{2}{*}{1} & 25 & 55 & $\mathrm{P} 0+0$ & 27wks & $\begin{array}{l}\text { MAE } \\
\mathrm{N}\end{array}$ & Mod & 10 & No & 35 & 0.24 & 0.86 \\
\hline & & & & $\begin{array}{l}\text { After } \\
\mathrm{t} / \mathrm{t}\end{array}$ & NO & No & 0 & No & 0 & 0.22 & 0.68 \\
\hline \multirow[t]{2}{*}{2} & 23 & 56 & $\mathrm{P} 0+1$ & 26wks & $\begin{array}{l}\text { MAE } \\
N\end{array}$ & Mod & 5 & Yes & 40 & 0.23 & 0.27 \\
\hline & & & & $\begin{array}{l}\text { After } \\
\mathrm{t} / \mathrm{t}\end{array}$ & E & Mild & 5 & No & 10 & 0.22 & 0.38 \\
\hline \multirow[t]{2}{*}{3} & 20 & 52 & $\mathrm{P} 0+0$ & 22wks & $\begin{array}{l}\text { MAE } \\
\mathrm{N}\end{array}$ & Mod & 10 & No & 10 & 0.03 & 0.17 \\
\hline & & & & After & NO & Mild & 5 & No & 5 & 0.01 & 0.19 \\
\hline
\end{tabular}


ORIGINAL ARTICLE

\begin{tabular}{|c|c|c|c|c|c|c|c|c|c|c|c|}
\hline & & & & $t / t$ & & & & & & & \\
\hline \multirow[t]{2}{*}{4} & 23 & 54 & $\mathrm{P} 1+1$ & 31wks & EN & Mod & 10 & Yes & 25 & 0.04 & 0.26 \\
\hline & & & & $\begin{array}{l}\text { After } \\
t / t\end{array}$ & NO & No & 0 & No & 0 & 0.01 & 0.29 \\
\hline \multirow[t]{2}{*}{5} & 28 & 50 & $\mathrm{P} 0+1$ & 23wks & MAE & Mild & 5 & No & 35 & 0.07 & 0.17 \\
\hline & & & & $\begin{array}{l}\text { After } \\
t / t\end{array}$ & NO & No & 0 & No & 0 & 0.08 & 0.32 \\
\hline \multirow[t]{2}{*}{6} & 21 & 48 & $\mathrm{P} 0+0$ & 23wks & $\begin{array}{l}\text { MAE } \\
\mathrm{N}\end{array}$ & Severe & 15 & No & 45 & 0.02 & 0.18 \\
\hline & & & & $\begin{array}{l}\text { After } \\
t / t\end{array}$ & $\mathrm{~N}$ & Mild & 5 & No & 10 & 0.03 & 0.17 \\
\hline \multirow[t]{2}{*}{7} & 23 & 46 & $\mathrm{P} 0+0$ & 16wks & MAE & Mild & 5 & No & 15 & 0.03 & 0.17 \\
\hline & & & & $\begin{array}{l}\text { After } \\
t / t\end{array}$ & NO & No & 0 & No & 0 & 0.3 & 0.04 \\
\hline \multirow[t]{2}{*}{8} & 25 & 50 & $\mathrm{P} 1+0$ & 30wks & AEN & Mod & 5 & No & 30 & 0.4 & 0.08 \\
\hline & & & & $\begin{array}{l}\text { After } \\
\mathrm{t} / \mathrm{t}\end{array}$ & NO & No & 0 & No & 0 & 0.09 & 0.31 \\
\hline \multirow[t]{2}{*}{9} & 27 & 59 & $\mathrm{P} 0+1$ & $29 w k s$ & MN & Severe & 10 & Yes & 15 & 0.07 & 0.13 \\
\hline & & & & $\begin{array}{l}\text { After } \\
\mathrm{t} / \mathrm{t}\end{array}$ & E & Mild & 5 & No & 5 & 0.08 & 0.22 \\
\hline \multirow[t]{2}{*}{10} & 22 & 45 & $\mathrm{P} 1+0$ & 20wks & MAE & Severe & 15 & Yes & 55 & 0.01 & 0.49 \\
\hline & & & & $\begin{array}{l}\text { After } \\
\mathrm{t} / \mathrm{t}\end{array}$ & $\mathrm{N}$ & Mild & 5 & No & 10 & 0.12 & 0.48 \\
\hline \multirow[t]{2}{*}{11} & 39 & 59 & $\mathrm{P} 1+1$ & $34 \mathrm{wks}$ & $\begin{array}{l}\text { MAE } \\
\mathrm{N}\end{array}$ & Mod & 5 & No & 20 & 0.19 & 0.21 \\
\hline & & & & $\begin{array}{l}\text { After } \\
t / t\end{array}$ & $\mathrm{E}$ & Mild & 5 & No & 5 & 0.08 & 0.32 \\
\hline \multirow[t]{2}{*}{12} & 30 & 80 & $\mathrm{P} 1+0$ & $32 \mathrm{wks}$ & $\begin{array}{l}\text { MAE } \\
\mathrm{N}\end{array}$ & Mild & 5 & Yes & 40 & 0.07 & 0.33 \\
\hline & & & & $\begin{array}{l}\text { After } \\
\mathrm{t} / \mathrm{t}\end{array}$ & NO & No & 0 & No & 0 & 0.1 & 0.3 \\
\hline \multirow[t]{2}{*}{13} & 20 & 45 & $\mathrm{P} 1+0$ & 18wks & MAE & Mod & 10 & No & 35 & 0.16 & 0.44 \\
\hline & & & & $\begin{array}{l}\text { After } \\
t / t\end{array}$ & $\mathrm{E}$ & Mild & 5 & No & 10 & 0.11 & 0.49 \\
\hline \multirow[t]{2}{*}{14} & 35 & 62 & $\mathrm{P} 0+0$ & 32wks & AN & Severe & 15 & Yes & 17 & 0.12 & 0.23 \\
\hline & & & & $\begin{array}{l}\text { After } \\
t / t\end{array}$ & E & Mild & 5 & No & 10 & 0.11 & 0.29 \\
\hline \multirow[t]{2}{*}{15} & 18 & 48 & $\mathrm{P} 0+0$ & 27wks & MAE & Severe & 10 & No & 35 & 0.05 & 0.25 \\
\hline & & & & $\begin{array}{l}\text { After } \\
\mathrm{t} / \mathrm{t}\end{array}$ & $\mathrm{N}$ & Mild & 5 & No & 10 & 0.04 & 0.26 \\
\hline \multirow[t]{2}{*}{16} & 22 & 43 & $\mathrm{P} 0+0$ & 35 & EN & Mod & 10 & Yes & 35 & 0.48 & 0.52 \\
\hline & & & & $\begin{array}{l}\text { After } \\
t / t\end{array}$ & NO & No & 0 & No & 0 & 0.38 & 0.64 \\
\hline \multirow[t]{2}{*}{17} & 20 & 52 & $\mathrm{P} 0+1$ & 36wks & MAE & Mod & 10 & Yes & 55 & 0.05 & 0.15 \\
\hline & & & & $\begin{array}{l}\text { After } \\
\mathrm{t} / \mathrm{t}\end{array}$ & $\bar{E}$ & Mild & 5 & No & 10 & 0.04 & 0.20 \\
\hline \multirow[t]{2}{*}{18} & 22 & 42 & $\mathrm{P} 0+0$ & 35wks & $\begin{array}{l}\text { MAE } \\
\mathrm{N}\end{array}$ & Severe & Mild & No & 65 & 0.19 & 0.14 \\
\hline & & & & $\begin{array}{l}\text { After } \\
\mathrm{t} / \mathrm{t}\end{array}$ & $\mathrm{N}$ & Mild & 5 & No & 10 & 0.22 & 0.32 \\
\hline
\end{tabular}


ORIGINAL ARTICLE

\begin{tabular}{|l|l|l|l|l|l|l|l|l|l|l|l|}
\hline 19 & 22 & 45 & P1+0 & $26 w k s$ & $\begin{array}{l}\text { MAE } \\
\text { N }\end{array}$ & Mild & 5 & No & 30 & 0.04 & 0.15 \\
\hline & & & $\begin{array}{l}\text { After } \\
\text { t/t }\end{array}$ & NO & No & 0 & No & 0 & 0.04 & 0.15 \\
\hline 20 & 27 & 54 & P1+0 & 22 wks & N & Mod & 10 & No & 35 & 0.07 & 0.33 \\
\hline & & & & $\begin{array}{l}\text { After } \\
\text { t/t }\end{array}$ & E & Mild & 5 & No & 10 & 0.04 & 0.15 \\
\hline
\end{tabular}

\begin{tabular}{|c|c|c|c|c|c|c|c|c|c|c|c|}
\hline Srl No & SGOT & SGPT & AlkPh & Sr Alb & Sr Glob & $\mathrm{Hb} \%$ & TC & Eosin & Sug & Urea & Creat \\
\hline 1 & 89 & 55 & 239 & 3 & 4.4 & 10.2 & 13500 & 1 & 81 & 10 & 1 \\
\hline After $\mathrm{t} / \mathrm{t}$ & 213 & 123 & 330 & 2.6 & 4.3 & 10 & 9000 & 1 & 83 & 8 & 0.6 \\
\hline 2 & 179 & 205 & 277 & 2.9 & 4 & 11.2 & 7200 & 4 & 112 & 10 & 0.4 \\
\hline After $\mathrm{t} / \mathrm{t}$ & 160 & 176 & 345 & 3 & 4 & 11.6 & 7500 & 4 & 109 & 14 & 0.4 \\
\hline 3 & 30 & 30 & 64 & 4 & 0.8 & 10.5 & 7700 & 2 & 107 & 7 & 0.5 \\
\hline After $\mathrm{t} / \mathrm{t}$ & 18 & 29 & 63 & 3.9 & 0.8 & 9.8 & 10200 & 2 & 87 & 7 & 0.6 \\
\hline 4 & 16 & 20 & 115 & 3 & 4.2 & 13 & 10500 & 1 & 66 & 7 & 0.4 \\
\hline After $\mathrm{t} / \mathrm{t}$ & 20 & 28 & 130 & 2.8 & 4.8 & 13.1 & 12600 & 1 & 68 & 6 & 0.5 \\
\hline 5 & 19 & 30 & 85 & 2.5 & 4.2 & 9.6 & 6600 & 2 & 112 & 6 & 0.8 \\
\hline After $\mathrm{t} / \mathrm{t}$ & 31 & 40 & 209 & 2.6 & 4.8 & 10.8 & 12400 & 1 & 75 & 24 & 0.76 \\
\hline 6 & 13 & 22 & 78 & 3.6 & 0.8 & 12.1 & 13900 & 3 & 85 & 24 & 0.7 \\
\hline After $\mathrm{t} / \mathrm{t}$ & 13 & 22 & 91 & 3.1 & 4.1 & 12.1 & 12700 & 1 & 94 & 7 & 0.3 \\
\hline 7 & 36 & 51 & 84 & 3.7 & 0.8 & 11.2 & 7300 & 4 & 106 & 7 & 0.6 \\
\hline After $\mathrm{t} / \mathrm{t}$ & 29 & 51 & 75 & 3.4 & 3 & 10.6 & 7600 & 3 & 90 & 6 & 0.4 \\
\hline 8 & 39 & 32 & 141 & 3.1 & 4.2 & 10.9 & 10700 & 5 & 84 & 20 & 0.9 \\
\hline After $\mathrm{t} / \mathrm{t}$ & 24 & 26 & 179 & 2.9 & 4 & 10.5 & 10000 & 5 & 86 & 18 & 0.6 \\
\hline 9 & 49 & 47 & 148 & 3.3 & 3.7 & 10.6 & 15000 & 2 & 99 & 8 & 0.5 \\
\hline After $\mathrm{t} / \mathrm{t}$ & 59 & 54 & 188 & 3.9 & 3.8 & 10.6 & 10900 & 4 & 87 & 6 & 0.5 \\
\hline 10 & 23 & 28 & 80 & 3.6 & 3.4 & 10.8 & 7000 & 5 & 82 & 7 & 0.6 \\
\hline After $\mathrm{t} / \mathrm{t}$ & 22 & 34 & 130 & 3.3 & 3 & 10.7 & 7900 & 4 & 80 & 5 & 0.5 \\
\hline 11 & 433 & 470 & 660 & 1.8 & 3.8 & 11.8 & 8000 & 2 & 82 & 16 & 0.8 \\
\hline After $\mathrm{t} / \mathrm{t}$ & 64 & 99 & 832 & 1.5 & 3 & 9.2 & 9600 & 2 & 70 & 14 & 0.7 \\
\hline 12 & 15 & 31 & 128 & 3.2 & 3.9 & 11.8 & 10600 & 5 & 74 & 8 & 0.6 \\
\hline After $\mathrm{t} / \mathrm{t}$ & 21 & 32 & 159 & 2.9 & 4 & 11.5 & 11000 & 4 & 72 & 16 & 0.5 \\
\hline 13 & 29 & 27 & 69 & 3.8 & 3.5 & 10.8 & 5700 & 5 & 85 & 7 & 0.6 \\
\hline After $\mathrm{t} / \mathrm{t}$ & 21 & 36 & 101 & 3.3 & 3 & 9.6 & 6300 & 3 & 75 & 7 & 0.6 \\
\hline 14 & 26 & 41 & 153 & 2.9 & 4.1 & 10.6 & 8802 & 2 & 117 & 8 & 0.7 \\
\hline After $\mathrm{t} / \mathrm{t}$ & 36 & 38 & 188 & 2.7 & 3 & 11.3 & 7500 & 2 & 124 & 6 & 0.6 \\
\hline 15 & 38 & 34 & 152 & 3.8 & 3.8 & 12.2 & 9700 & 4 & 89 & 8 & 0.8 \\
\hline After $\mathrm{t} / \mathrm{t}$ & 24 & 35 & 221 & 3.3 & 3.9 & 13.3 & 9400 & 4 & 73 & 6 & 0.6 \\
\hline 16 & 62 & 82 & 515 & 2.6 & 3.4 & 13.1 & 9400 & 1 & 71 & 12 & 0.6 \\
\hline After $\mathrm{t} / \mathrm{t}$ & 64 & 80 & 520 & 2.8 & 3.8 & 11.2 & 18600 & 1 & 82 & 15 & 0.6 \\
\hline 17 & 29 & 28 & 224 & 2 & 4.3 & 9.8 & 8600 & 2 & 77 & 8 & 0.6 \\
\hline After $\mathrm{t} / \mathrm{t}$ & 20 & 20 & 252 & 2.8 & 4.1 & 10.8 & 12600 & 7 & 70 & 4 & 0.5 \\
\hline 18 & 75 & 77 & 352 & 2 & 3.9 & 10.8 & 6100 & 3 & 103 & 9 & 0.6 \\
\hline After $\mathrm{t} / \mathrm{t}$ & 35 & 44 & 437 & 2.3 & 2.8 & 9.5 & 8900 & 1 & 88 & 4 & 0.4 \\
\hline 19 & 16 & 25 & 95 & 3 & 3.4 & 9.7 & 7900 & 3 & 66 & 7 & 0.6 \\
\hline After $\mathrm{t} / \mathrm{t}$ & 15 & 24 & 103 & 3 & 3.4 & 9.6 & 7000 & 2 & 86 & 8 & 0.5 \\
\hline 20 & 57 & 68 & 139 & 4 & 0.6 & 8 & 8900 & 2 & 111 & 16 & 0.6 \\
\hline After $\mathrm{t} / \mathrm{t}$ & 15 & 25 & 105 & 3 & 1.7 & 7.9 & 13100 & 3 & 89 & 20 & 0.6 \\
\hline
\end{tabular}

